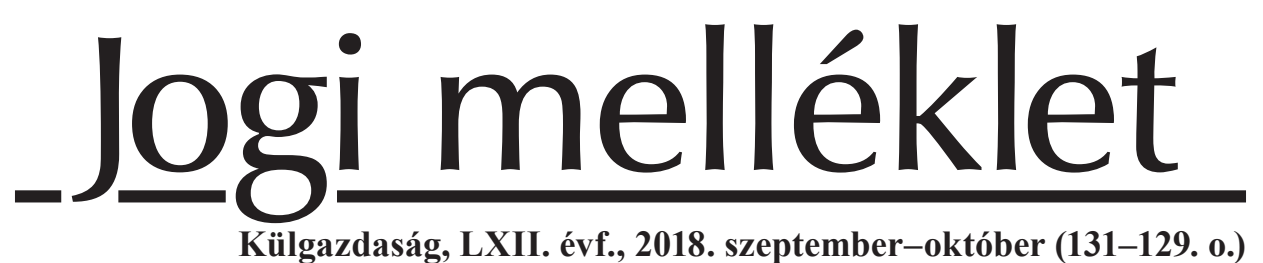

\title{
Az Európai Unió nemzetközi jogi felelősségéről KNAPP LÁSZLÓ
}

A nemzetközi szervezetek felelössége a nemzetközi jog olyan területének minösül, amelynek eddigi alakitására a gyakorlatban felmerült kérdések mellett ezen entitások belsö sajátosságai is jelentös hatást gyakoroltak. Különösen igaz ez az Európai Közösségeket, illetve jelenleg az Európai Uniót érintö felelösségi ügyekre, valamint e szervezetek jogrendszerére. A tanulmány célja annak megvizsgálása, hogy a gyakorlat és a jogalkotás ezen interakciója milyen megoldásokat hívott életre és ezek miként alkalmazhatóak az Európai Unió esetén. Ezt szem elött tartva a munka röviden bemutatja a nemzetközi szervezetek felelösségének evolúcióját, elemzi az ENSZ Nemzetközi Jogi Bizottsága által kidolgozott, a szervezetek felelösségére vonatkozó tervezetet, illetve feldolgozza a nemzetközi bírói fórumok gyakorlatának a téma szempontjából lényegesebb elemeit.

Journal of Economic Literature (JEL) kód: K33 International Law, K39 Other.

\section{Bevezető}

Az elmúlt évtizedek fejlődésének eredményeként a nemzetközi közösség életét egyre nagyobb mértékben alakítják - a nemzetközi jog alanyaiként is elismert - különböző nemzetközi szervezetek, amelyek között jogi-intézményi szerkezetük révén kiemelt szerepet töltöttek és töltenek be az európai integrációs szervezetek. A korábban az államok kapcsán használt kategóriáknak és jogintézményeknek a szer-

https://doi.org/10.47630/KULG.2018.62.7-8.131

Knapp László, egyetemi tanársegéd, Széchenyi István Egyetem Deák Ferenc Állam- és Jogtudományi Kar, Nemzetközi Köz- és Magánjogi Tanszék. E-mail: knapplaszlo@sze.hu 
vezetekre történő alkalmazása idővel számos kérdést vetett fel, melyek közül többre a nemzetközi jog jelenleg is igyekszik megfelelö választ találni. Ilyennek minősül - a valamennyi jogrendszer egyik legérzékenyebb elemének tekintendő - felelösség tárgyköre is, amely a nemzetközi jog eredeti alanyainak számító államok esetén is viszonylag fejletlen kategória, de különösen igaz ez a tőlük származó hatáskörök alapján müködő nemzetközi szervezetek vonatkozásában.

\section{A nemzetközi szervezetek nemzetközi jogi felelősségének evolúciója}

Míg korábban a nemzetközi jog szabályainak megsértése kizárólag az államok felelősségének kérdését vetette fel, addig a 20. századi, de különösen a második világháborút követő jogfejlődés felszínre hozta a nemzetközi szervezetek felelősségének, illetve igényérvényesítésének problematikáját.

A Nemzetközi Bíróság az Egyesült Nemzetek szolgálatában elszenvedett károk miatti kártérités ügyében kiadott tanácsadó véleményében ${ }^{1}$ nemcsak a világszervezet nemzetközi jogi személyiségét mondta ki, hanem ebböl az ENSZ igényérvényesítési képességét is levezette. ${ }^{2}$ Lényeges a kárfelelősséggel összefüggésben tett azon megállapítása, hogy ez nem nemzeti jogi, hanem nemzetközi jogi kötelezettség megszegéséből eredt, ennélfogva az ügy tárgya nemzetközi igény, illetve az ENSZ ezzel kapcsolatos fellépési képessége volt, amelyet a Nemzetközi Bíróság megerősített. ${ }^{3}$ A jogképességgel összefüggő kérdés rendezésén felül azonban a dokumentum nem szól arról, hogy milyen bírói testület előtt lett volna lehetséges érvényesíteni ezt az igényt. ${ }^{4} \mathrm{E}$ hallgatás hátterében az állt, hogy akkor még valójában nem léteztek olyan igazságszolgáltató fórumok, amelyek előtt a nemzetközi szervezetek eljárhattak volna.

Idővel a nemzetközi szerződések joga is reagált arra a folyamatra, hogy a szervezetek egyre nagyobb számú két- és többoldalú megállapodás részes feleivé válnak. Elsőként a veszélyeztetett vadon élő állat- és növényfajok nemzetközi kereskedelméről szóló, 1973. évi washingtoni egyezmény (Convention on International Trade in

${ }^{1}$ Reparation for injuries suffered in the service of the United Nations, Advisory Opinion: I.C. J. Reports 1949. (Reparation for injuries...) 174. o.

2 Lamm [1995], 408-409. o.

${ }^{3}$ Reparation for injuries..., 179-184. o.

${ }^{4}$ Evans-Okowa [2013], 105. o. 
Endangered Species of Wild Fauna and Flora, CITES) 1983. évi kiegészítése ${ }^{5}$ használta az ún. regionális gazdasági integrációs szervezet (Regional Economic Integration Organisation, REIO) fogalmat, ${ }^{6}$ lehetővé téve számukra az egyezményhez való csatlakozást. A gyakorlatban e kategóriát az Európai Unióra és elődszervezeteire alkalmazzák. ${ }^{7}$ Későbbi nemzetközi szerződések igyekeztek e fogalmat tartalommal megtölteni, például olyan értelmező rendelkezések beillesztésével, hogy a „regionális gazdasági integrációs szervezet [...] tájékoztatja a letéteményest [...] az egyezmény által szabályozott ügyekben meglévő illetékességéről és az abban a későbbiekben bekövetkező változásokról. Az érintett szervezet az illetékességébe tartozó ügyekben gyakorolja azokat a jogait és teljesíti azokat a kötelezettségeit, amelyeket ez az egyezmény a szerződő felekre keletkeztet."

Ugyanebben az időszakban az ENSZ 1982. évi Tengerjogi Egyezményében ${ }^{9}$ (United Nations Convention on the Law of the Sea, UNCLOS) jelent meg a nemzetközi szervezetek ún. hatásköri nyilatkozat megtételére vonatkozó kötelezettsége, amely tartalmazta, hogy a tagállamok mely, az egyezmény teljesítésével összefüggő hatásköreiket ruházták a szervezetre. ${ }^{10} \mathrm{E}$ nyilatkozat konstitutív természetủ azáltal, hogy a tartalmának megfelelő mértékig válik a nemzetközi szervezet az egyezmény részesévé. Mindemellett vélelem keletkezik arra vonatkozóan, hogy azokkal a hatáskörökkel, melyeket a nyilatkozat kifejezetten nem tulajdonított a nemzetközi szervezeteknek, továbbra is annak tagállamai rendelkeznek, amennyiben azok az UNCLOS szerződő felei. ${ }^{11}$ Lényeges, hogy e dokumentum képezi a felelősség alapját is, illetve bármely szerződő állam tájékoztatást kérhet a nemzetközi szervezettől vagy annak az egyezményben részes tagállamától, hogy kit terhel a felelősség - ez utóbbi elmaradása vagy nem megfelelő tartalmú kiállítása a szervezet és a tagállamai egye-

${ }^{5}$ A Tanács (EU) 2015/451 határozata (2015. március 6.) az Európai Uniónak a veszélyeztetett vadon élő állat- és növényfajok nemzetközi kereskedelméről szóló egyezményhez (CITES) való csatlakozásáról. HL L 75., 2015.3.19., 1. o.

${ }^{6}$ CITES, XXI. cikk.

${ }^{7}$ Kuijper [2010], 221-222. o.

8 A Tanács 95/137/EK határozata (1995. április 7.) a nemzetközi fuvarozás közös használatú konténereinek vámkezeléséről szóló egyezménynek (Genf, 1994. január 21.) a Közösség részéről való, megerösítés fenntartása nélküli aláírásáról. HL L 91., 1995.4.22., 45. o.; magyar különkiadás: 2. fejezet, 5. kötet, 387. o., 14. cikk (3) bekezdés. Idézi: Heliskoski [2013], 198. o.

9 A Tanács 98/392/EK határozata (1998. március 23.) az Egyesült Nemzetek Szervezete 1982. december 10-i tengerjogi egyezményének és az egyezmény XI. részének végrehajtásáról szóló, 1994. július 28-i megállapodásnak az Európai Közösség általi megkötéséröl. HL L 179., 1998.6.23., 1. o.; magyar különkiadás: 4. fejezet, 3. kötet, 260. o.

${ }^{10}$ UNCLOS, IX. melléklet, 5. cikk (1) bekezdés.

${ }^{11}$ Uo., IX. melléklet, 4. cikk (2) bekezdés és 5. cikk (3) bekezdés. 
temleges felelősségét eredményezik. ${ }^{12}$ Az egyezmény említett rendelkezését különböző formákban számos nemzetközi szerződés átvette, amelynek eredményeként az Európai Unió jelenleg hozzávetőleg harminc ilyen nyilatkozat megtételét elöíró megállapodás részes fele. ${ }^{13}$

A kilencvenes évek újabb fordulatot hozott az európai integrációs szervezetek nemzetközi jogi felelőssége vonatkozásában. Egyrészt a tagállamai mellett az Európai Közösség is a WTO-egyezmény14 szerződő felévé, illetve a Kereskedelmi Világszervezet (World Trade Organization, WTO) alapító tagjává vált, amely azt eredményezte, hogy a WTO égisze alatt kialakított vitarendezés keretében eljárást indíthat, illetve vele szemben is eljárás indítható. E Vitarendezési Testület (Dispute Settlement Body, DSB) gyakorlata nagyban hozzájárult nemcsak az EU, hanem a nemzetközi szervezetek felelősségéről alkotott felfogások továbbfejlesztéséhez.

A kétezres évek kezdetétől elindult alapszerződési reformfolyamat prioritásként kezelte a külkapcsolatok terén a hatékonyabb európai uniós fellépés jogi kereteinek kialakítását. ${ }^{15} \mathrm{Az}$ Alkotmányos Szerződésben ilyen tárgyú rendelkezéseinek többségét a Lisszaboni Szerződés is átvette, amelynek a legátfogóbb jellegü eredménye az lett, hogy az Európai Közösség helyett az Európai Unió vált a nemzetközi kapcsolatokban eljárni képes, fő európai integrációs szervezetté. ${ }^{16}$ E folyamattal gyakorlatilag párhuzamosan az ENSZ Nemzetközi Jogi Bizottsága kidolgozta az államok, majd a nemzetközi szervezetek felelősségéről szóló tervezeteket. ${ }^{17}$

\section{Az EU nemzetközi jogi felelősségének keretei - A Nemzetközi Jogi Bizottság tervezete}

A nemzeti jogrendszerekhez képest a nemzetközi jog felelősségrendszere jóval fejletlenebb, amely sajátosság leginkább a szabályozás és a fórumrendszer hiányos-

12 Uo., IX. melléklet, 6. cikk (1)-(2) bekezdések.

13 Heliskoski [2013], 189-190. o.

14 A Tanács 94/800/EK-határozata (1994. december 22.) a többoldalú tárgyalások uruguayi fordulóján (1986-1994) elért megállapodásoknak az Európai Közösség nevében történő megkötéséről. HL L 336., 1994.12.23, 1. o.; magyar különkiadás 11. fejezet, 21. kötet, 80. o. Az egyezmény magyar nyelvü szövege az azt Magyarországon kihirdető törvényben található: 1998. évi IX. törvény az Általános Vám- és Kereskedelmi Egyezmény (GATT) keretében kialakított, a Kereskedelmi Világszervezetet létrehozó Marrakesh-i Egyezmény és mellékleteinek kihirdetéséről.

15 Lásd a 2001. decemberi laekeni nyilatkozat erre vonatkozó részeit. Cremona [2008], 34-37. o.

16 Európai Unióról szóló Szerződés (EUSz) 1. cikk.

17 Lásd alább. 
ságaiban érhető tetten. Ennek oka a nemzetközi közösség, illetve a nemzetközi jog azon jellegadó tulajdonságában keresendő, hogy nem létezik elkülönült jogalkotó fórum, hanem a jogalanyok gyakorlatilag magukra nézve állapítanak meg jogokat és kötelezettségeket. Mindezek alapján az általános jellegủ felelősségi kérdések nemzetközi szerzödésben történő rendezése széles körü felfogásbeli - és sok szempontból politikai - kompromisszumot igényelne, amiről jelenleg nem beszélhetünk. Az államok mellett igaz mindez a nemzetközi szervezetek - amely kategóriába nemzetközi jogi szempontból az Európai Unió is tartozik - felelősségi kérdéseire is, amelyek a tagországaik közötti együttmúködés számára adnak gyengébb vagy mélyebb integrációs keretet.

Habár sem az államok, sem a nemzetközi szervezetek felelőssége vonatkozásában nem létezik az általános kérdéseket rendezni hivatott nemzetközi szerződés, mindkét entitástípus kapcsán az ENSZ Nemzetközi Jogi Bizottsága kidolgozott ún. „tervezett cikkeket”, amelyek 2001-re, ${ }^{18}$ illetve $2011-$ re $^{19}$ készültek el. Mindkét anyag és a hozzájuk készített kommentárok is arra utalnak, hogy megalkotásuk célja nem elsődlegesen egy későbbi nemzetközi szerződés tervezetének kidolgozása volt, hanem a nemzetközi joggyakorlat révén kialakult, általános szabályokat igyekeztek összefoglalni.

A „Tervezett cikkek a nemzetközi szervezetek felelősségéröl” (Draft Articles on the Responsibility of International Organizations, DARIO) címú anyag tartalmazza a nemzetközi szervezetek fogalmát - amely egyébként e kategória elemeként tekint a jogi személyiség meglétére -, azonban a meghatározás beillesztésének célja nem egy általános definíció megadása volt, hanem pusztán az anyag hatályának rögzítése. ${ }^{20}$ A DARIO középpontjában, a felelősség alapjaként az ún. „nemzetközi jogellenes aktus" (,internationally wrongful act”) áll; ez olyan cselekményt vagy mulasztást jelent, amely a nemzetközi jog szabályai szerint a nemzetközi szervezetnek tulajdonítható és a szervezet nemzetközi kötelezettségei megsértésének minősül. ${ }^{21}$

A jogellenesség fogalmi elemeinek magyarázataként gyakorlatilag utaló szabályokat tartalmaz az anyag. Egyrészt kimondja, hogy a szervezetek aktusainak nemzetközi jogellenességére a nemzetközi jog irányadó. ${ }^{22}$ Másrészt a fent említett nem-

18 Draft Articles on Responsibility of States for Internationally Wrongful Acts, with commentaries. Yearbook of the International Law Commission, 2001. Vol. II, Part Two. 31. o.

19 Draft Articles on the Responsibility of International Organizations. Yearbook of the International Law Commission, 2011. (DARIO) Vol. II., Part Two. 2. o.

20 DARIO, 49. o.

21 Uo., 4. cikk.

22 Uo., 5. cikk. 
zetközi kötelezettség megszegésének esetét úgy adja meg, hogy a szervezet aktusa nincs összhangban azzal, ami a kötelezettsége alapján tőle elvárt, tekintet nélkül e kötelezettség eredetére vagy jellegére. ${ }^{23}$ Ennélfogva a nemzetközi jogsértés alapja tipikusan a szervezet számára is kötelezettséget megállapító nemzetközi szerződés és a nemzetközi szokásjogi normák lehetnek. Ami az Európai Unió szempontjából különösen érdekes, hogy ugyanezen cikk a nemzetközi kötelezettségek közé sorolja a szervezetnek a tagállamaival szemben fennálló kötelezettségeit is, amelyek öt a „szervezet szabályai” alapján terhelik. ${ }^{24}$

A későbbi értelmezési kérdések vonatkozásában is lényeges a „szervezet szabályai" megnevezésü kategória, amely alatt a DARIO elsődlegesen a szervezet alapvető, alkotmányos jellegü rendelkezéseit, döntéseit, határozatait, és az alapvető rendelkezésekkel összhangban elfogadott aktusait érti, ideértve a szervezet gyakorlatát is. ${ }^{25}$

A felelősségi rendelkezésekkel összefüggő operatív kérdés, hogy milyen esetben lehet a jogellenesnek vélt aktusokat a szervezetnek tulajdonítani. Erre a beszámítási szabályokat tartalmazó II. fejezet ad választ. A 6. cikk gerincét a nemzetközi szervezet „szervének vagy alkalmazottjának cselekménye” képezi, tekintet nélkül a helyzetére, illetve a pozíciójára. A szervi, illetve alkalmazotti minőség meghatározását a DARIO szintén a szervezet szabályaira bízza. ${ }^{26}$

E megközelítés a nemzetközi szervezetek többségénél megfelelőnek tűnik, azonban az Európai Unió esetén több problémát vet fel. Egyrészt az EU kiterjedt intézményrendszerrel rendelkezik, és a nemzetközi felelősségét érintő kérdések vonatkozásában a fő intézmények mellett az Európai Külügyi Szolgálat, a külügyi és biztonságpolitikai fő képviselő és az uniós delegációk bármilyen aktusai is relevanciával bírhatnak. Ugyanakkor az uniós jog legfőbb végrehajtói a tagállamok, ami nehézséget eredményezhet a felelősség megállapíthatósága szempontjából, ugyanis a tagállamok szuverének maradtak, intézményeik formálisan nem váltak az Unió szerveivé. $^{27}$

A végrehajtás e sajátos természete miatt a DARIO-nak az a cikke sem jelent megoldást az Unió és a tagállamok közötti felelősségi kérdésekre, amely az államok és a nemzetközi szervezetek részéről egy másik nemzetközi szervezet számára rendelkezésre bocsátott szervekről és alkalmazottakról szólnak. Az ezt szabályozó cikk alapvetően az ENSZ békefenntartó misszióinak müködése során felmerült kérdések

${ }^{23}$ Uo., 10. cikk (1) bekezdés.

${ }^{24}$ Uo., 10. cikk (2) bekezdés.

${ }^{25}$ Uo., 2. cikk (b) pont.

${ }^{26}$ Uo., 6. cikk.

${ }^{27}$ Kuijper-Paasvirta [2013], 50-54. o. 
miatt került az anyagba, ${ }^{28}$ és a rendelkezés értelmében a felelősség megállapításánál azt szükséges megvizsgálni, hogy a nemzetközi szervezet, illetve a küldő állam vagy nemzetközi szervezet gyakorolta-e a tényleges irányítást, ellenőrzést (,effective control"). ${ }^{29}$ E szabályozás megfelelőnek tünik az Unió békefenntartó misszióinak és katonai müveleteinek müködése során esetleg felmerülő felelősségi kérdések

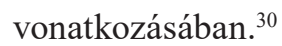

Az Unió és a tagállamok viszonya felvet egy másik, egyébként sok más esetben érzékeny tényezőt, a szervezet és a tagállamai közötti hatáskörmegosztás kérdését. Mindez nem minősül a DARIO központi elemének, illetve az említett beszámítási szabályok sem a hatáskörök köztük lévő puszta fennállásán, hanem a kompetenciák tényleges gyakorlásán alapulnak, azonban ez nem zárja ki, hogy a tagállami szervek aktusai a szervezetnek legyenek tulajdoníthatóak. ${ }^{31}$

A Nemzetközi Jogi Bizottság ezen megközelítése leginkább a szervezet szabályainak relevanciájáról szóló rendelkezések kapcsán érhető tetten. ${ }^{32}$ Itt a DARIO egyrészt azt mondja ki, hogy a szervezet nem hivatkozhat a saját szabályaira a kötelezettségei elmulasztásának igazolásául, másrészt - az előzőek „sérelme nélkül” - lehetővé teszi a tagállamaival ${ }^{33}$ fennálló kapcsolatát rendező szabályok alkalmazását. ${ }^{34}$ A DARIO kommentárja alapján e rendelkezés azon esetekre vonatkozik, amikor a szervezet nemzetközi felelősséggel tartozik a tagjai felé, ám mindez semmi esetre sem korlátozhatja a „külső” államok és nemzetközi szervezetek irányában fennálló felelősségét. ${ }^{35}$

Ami az Európai Unió és a tagállamai között fennálló sajátos viszonyrendszerre tekintettel megoldást jelenthet, az a DARIO „lex specialis” címet viselő 64. cikke. E rendelkezések gyakorlatilag kizárják a „Tervezett cikkek” alkalmazhatóságát, amennyiben a nemzetközi jogellenes aktusra, vagy a nemzetközi felelősség tartalmára, illetve alkalmazására a „nemzetközi jog különös szabályai” vonatkoznak. A cikk szerint ilyennek minősülnek a nemzetközi szervezet és a tagjai viszonyára vonatkozó rendelkezések.

${ }^{28}$ DARIO, 56-57. o.

${ }^{29}$ Uo., 7. cikk.

${ }^{30}$ Kuijper-Paasvirta [2013], 54. o.

${ }^{31}$ Heliskoski [2013], 194-195. o.

32 Sokat elmond a Nemzetközi Jogi Bizottság szemléletéröl, hogy a DARIO korábbi, 2009-es változatában mindez még ,a szervezet szabályainak irrelevanciája” címet viselte.

${ }^{33}$ A rendelkezés ide sorolja azon nemzetközi szervezeteket is, amelyek az adott nemzetközi szervezet tagjai.

${ }^{34}$ DARIO, 32. cikk.

${ }^{35}$ Uo., 78. o. 
E szabályok 2009-ben kerültek a „Tervezett cikkek” közé, és ahogy a DARIO kommentárjából kiderül, elsődlegesen az Európai Uniót (illetve korábban az Európai Közösséget) érintő eljárások során felmerült kérdések motiválták beillesztésüket. ${ }^{36}$ Első olvasatra úgy tünik, hogy a rendelkezés nem alkalmazható az Unió és a tagállamok viszonyára, mivel azt nem a nemzetközi jog, hanem az uniós jog szabályozza. ${ }^{37}$ Ezzel szemben Giorgio Gaja, a téma raportőre a szélesebb értelmezés híve, amit azzal támaszt alá, hogy a nemzetközi jog e „,különös szabályai” a DARIO által alkalmazott „szervezet szabályai” kategóriába tartoznak, amelyre konkrét példaként az Európai Unió jogának az EU és a tagállamok közötti viszonyát rendező szabályait hozza fel..$^{38}$

Jellegéből adódóan a DARIO nem elsődlegesen az Európai Unió, hanem általában a nemzetközi szervezetek felelősségi kérdései vonatkozásában nyújthat segítséget, ugyanakkor érezhető megalkotóinak arra irányuló szándéka, hogy az anyag az EU esetén is alkalmazható legyen. A „Tervezett cikkek” a nemzetközi szervezetek felelősségének csupán egy általános keretrendszerét adják meg, a felelősség alapjának és tartalmának meghatározását a nemzetközi jog szabályaira bízzák.

\section{Az Európai Unió nemzetközi jogi felelősségének főbb típusai és megjelenési formái}

A nemzetközi szervezetek felelősségének anyagi jogi hátterét tehát a nemzetközi jog vonatkozó szabályai adják meg. A felelősségi jog nemzeti jogrendszerekből eredő kategóriái ebben az esetben is segítségül hívhatók, amely értelemben a szerzödéses felelösség itt a megkötött nemzetközi szerződésekért való felelősséget jelenti, a szerzödésen kívüli felelösség alapját pedig elsődlegesen a nemzetközi szokásjog képezi. ${ }^{39}$ Tekintettel a szervezetek szerepének korábban vázolt fejlődésére, a kettő közül a szerződéses felelősséggel összefüggő kérdések bírnak nagyobb gyakorlati jelentőséggel, különösen igaz ez az Unió és a tagállamok részvételével kötött, ún. vegyes szerződések által felvetett problémákra. ${ }^{40} \mathrm{Az}$ EU szerződésen kívüli felelőssége egyelőre elméleti kategória, de a későbbiekben különösen a biztonság- és védelem-

36 Uo., 102-103. o.

37 Rosas [2013], 151-152. o.

38 Gaja [2018], 3. o.

39 Kuijper-Paasvirta [2013], 36. o.

40 Lásd erről: Kuijper [2010], 208. o. 
politikai égisze alatt folytatott polgári és katonai mủveletek számának növekedése révén merülhetnek fel ilyen jellegü kérdések. ${ }^{41}$

Azonban nemcsak a felelösségre vonatkozó anyagi jogi rendelkezések tekinthetök sporadikusnak, hanem az eljárási jogi szabályok köre - illetve a nemzetközi szervezetek felelősségi tárgyú eljárásban való részvételének lehetősége - is pusztán néhány nemzetközi bírói testületre korlátozódik. Mindezen sajátosságok miatt az Európai Unió nemzetközi jogi felelösségének feltérképezésére leginkább az ún. induktív módszer alkalmas, amely az eljárt nemzetközi bírói fórumok kapcsolódó gyakorlatának elemzését jelenti.

\section{IV.1. A Nemzetközi Bíróság}

Keletkezési körülményeivel összhangban a Nemzetközi Bíróság Statútuma (Nemzetközi Bíróság Alapszabályai) ${ }^{42}$ is csak államok számára teszi lehetővé, hogy az egyes ügyekben félként eljárjanak. ${ }^{43}$ Ugyanakkor az ezt szabályozó 34 . cikk a Bíróság részére adatkérési lehetőséget és információnyújtási kötelezettséget ír elő a nemzetközi szervezetek irányába az ezeket érintő esetekben.

A Nemzetközi Bíróság elé az ún. Halászati joghatóság-üggyel ${ }^{44}$ került olyan eset, amelyben - igaz, pusztán érintőlegesen - megjelent az Európai Unió. A Kanada és Spanyolország közötti jogvita alapját az képezte, hogy Kanada 1994-ben akként módosította a parti halászat védelméről szóló törvényét, hogy annak területi hatályát kiterjesztette az Észak-atlanti Halászati Szervezet (Northwest Atlantic Fisheries Organization, NAFO) szabályozási területére (Regulatory Area) a szervezetet mai formájában létrehozó 1978. évi egyezmény ${ }^{45}$ céljaival összhangban, majd a módosított szabályozás alapján 1995 márciusában lefoglalta az ott spanyol lobogó alatt közlekedő Estai nevü halászhajót. ${ }^{46}$ Mivel az EK az említett NAFO-egyezménynek az

${ }^{41}$ Wessel-Den Hertog [2013], 347. o.

${ }^{42}$ A Statútum szövege megtalálható: 1956. évi I. törvény az Egyesült Nemzetek Alapokmányának törvénybe iktatásáról.

43 A Nemzetközi Bíróság Alapszabályai, 34. cikk.

${ }^{44}$ Fisheries Jurisdiction (Spain v. Canada), Jurisdiction of the Court, Judgment, I. C.J. Reports 1998. 432. o.

45 A Tanács 3179/78/EGK rendelete (1978. december 28.) az északnyugat-atlanti halászatban folytatandó jövőbeni többoldalú együttműködésről szóló egyezménynek az Európai Gazdasági Közösség általi megkötéséről. HL L 378., 1978.12.30., 1. o.; magyar különkiadás: 4. fejezet, 1. kötet, 9. o.

${ }^{46}$ Fisheries Jurisdiction, 1. pont. 
aláirása óta részes fele volt, az ügyben a Közösség és a tagállamai közösen küldtek szóbeli jegyzéket a kanadai külügyminisztériumba. ${ }^{47}$

A Statútum fenti rendelkezésére tekintettel a Nemzetközi Bíróság előtti eljárást Spanyolország önállóan indította meg 1995. március 28-án, azonban a testület végül nem járt el, mivel Kanada 1994-ben tett fenntartása kizárta a joghatóságát, illetve az EK és Kanada között jegyzékváltás útján 1995 áprilisában kötött szerződés okafogyottá tette az eljárást. ${ }^{48} \mathrm{~A}$ Bíróság álláspontja különösen érdekes lett volna ebben az esetben, ugyanis a NAFO-egyezménynek az Európai Közösség volt a részes fele, Spanyolország nem, amely így olyan tárgykörre vonatkozó felelösségi kérdésben járt volna el, amely időközben közösségi hatáskörbe került. ${ }^{49}$ Ítéletét a Bíróság azzal zárta, hogy mivel joghatóság hiánya miatt nem járhatott el, nem volt köteles megvizsgálni, hogy az EK-Kanada szerződésen alapuló vitán kívüli jogvitáról volt-e szó. ${ }^{50}$ Mindez arra enged következtetni, hogy távol tartotta volna a saját eljárásától a nemzetközi szervezet részvételét eredményezö, vagy kizárólag a szervezet és egy harmadik állam között kötött szerződésen alapuló felelősségi kérdés megvizsgálását.

\section{IV.2. Az Emberi Jogok Európai Bírósága}

Jóval összetettebb az Európai Unió és az Emberi Jogok Európai Bíróságának (EJEB) viszonya. Az emberi jogok és alapvető szabadságok védelméről szóló, 1950. évi római egyezmény ${ }^{51}$ (Emberi Jogok Európai Egyezménye, EJEE) alapján felállított testület - az EJEE többszöri kiegészítése, illetve az EJEB eljárásának hatékonyabbá tétele révén - az emberi jogok védelmének mintaértékủ regionális fórumává vált. $\mathrm{Az}$ Európai Közösségek alapszerződési kereteinek kialakításakor nem fektettek hangsúlyt az emberi jogi rendelkezésekre, ugyanakkor a megvalósítani kívánt gazdasági integráció az ún. alapszabadságokat akadályozó különböző tagállami intézkedések lebontásán alapult, amely az egyének esetén magában foglalta az állampolgárságon alapuló diszkrimináció tilalmát.

47 Uo., 20. pont.

48 Uo., 87-88. pontok.

49 Evans-Okowa [2013], 105-106. o.

50 Fischeries Jurisdiction, 88. pont.

51 Magyarországon kihirdette: 1993. évi XXXI. törvény 1993. évi XXXI. törvény az emberi jogok és az alapvető szabadságok védelméről szóló, Rómában, 1950. november 4-én kelt Egyezmény és az ahhoz tartozó nyolc kiegészítő jegyzőkönyv kihirdetéséröl. 
Az Európai Bíróság az ítéletei révén lépésről lépésre erősítette meg az alapvető jogok jelenlétét a közösségi jogban, illetve közeledett a strasbourgi fórum gyakorlatához. Már az 1969-ből származó, Stauder-ítéletében ${ }^{52}$ kimondta, hogy az alapvető jogok a közösségi jog általános jogelveinek integráns részét képezik, amelyek védelme a bíróság feladata. A Nold-ügyben ${ }^{53}$ a tagállamok által kötött emberi jogi tárgyú nemzetközi szerződések által adott iránymutatásoknak a közösségi jog keretei között történő követését írta elö, és az adott ügy kapcsán konkrétan megnevezte az EJEE-t. Mindez a maastrichti szerződés révén alapszerződési megerősítést is kapott annak kimondásával, hogy az Unió tiszteletben tartja az alapvető jogokat, ahogy azokat az egyezmény biztosítja. ${ }^{54}$

Habár sem az Európai Közösségek, sem az EU nem vált az EJEE szerződő felévé, az Emberi Jogok Európai Bírósága több olyan ítéletet hozott, amelyekben - legalábbis közvetve - közösségi jogi rendelkezést vizsgált. A Melchers-eset ${ }^{55}$ előzménye az volt, hogy egy német társaságot az Európai Bizottság versenyjogi jogsértés miatt bírsággal sújtotta, amit az Európai Bíróság is megerősített. A végrehajtás miatt a társaság kártérítési pert indított a német állam ellen, majd a nemzeti jogorvoslati fórumok kijárását követően a strasbourgi fórumhoz - az akkor hatályos intézményi-eljárási szabályok alapján az Emberi Jogok Európai Bizottságához - fordult. Ítéletében a testület hangsúlyozta, hogy Németország nem vonható felelősségre a közösségi intézmények aktusaiért, különösen mivel a közösség nem részes fele az egyezménynek. Ugyanakkor ezen - és bármely más nemzetközi szervezet - intézkedéseinek tagállami alkalmazása és végrehajtása a strasbourgi fórum vizsgálatának tárgya lehet, kivéve ha az érintett szervezet biztosítja az alapjogok „hasonló mértékü" védelmét. Következtetésében a Bizottság ilyennek minősítette az EK-t. ${ }^{56}$

E megalapozást kritikusabb ítéletek követték. A Matthews-ügy ${ }^{57}$ előzményét az európai parlamenti választásokról szóló határozathoz csatolt okmány azon melléklete képezte, amely kizárta a Gibraltáron élő brit állampolgárokat az e választáson való részvételből. Mivel ez nem intézményi aktusként lett elfogadva - amely vonatkozásában a strasbourgi fórum eljárása kizárt -, hanem nemzetközi szerződésként, felmerült az Egyesült Királyság felelősségének megállapíthatósága az EJEE-ben

52 1969. november 12-i Stauder kontra Stadt Ulm-ítélet, 29/69, EU:C:1969:57, 7. pont.

53 1974. május 14-i Nold KG kontra Bizottság-ítélet, 4/73, EU:C:1974:51, 12-13. pontok.

${ }^{54}$ Szerződés az Európai Unióról (1992), F. cikk.

${ }_{55}$ M \& Co v. Federal Republic of Germany, no. 13258/87, D.R. No. 64, 138. o.

56 Szalayné [2009], 374-375. o.

${ }^{57}$ Matthews v. the United Kingdom [GC], no. 24833/94, ECHR 1999-I, 251. o. 
garantált választási jog megsértéséért. ${ }^{58} \mathrm{~A}$ strasbourgi fórum az ítéletét részint az elsődleges és a másodlagos jogforrások közötti különbségtételre alapozta. Tekintettel arra, hogy az előbbieket a luxembourgi Európai Bíróság nem vizsgálhatta felül, joghézag maradt az ilyen formában megvalósított jogsértések esetén. ${ }^{59}$ Mivel az Egyesült Királyság szuverén államként fogadta el az érintett okmányt, az EJEB végül megállapította az Egyesült Királyság felelősségét arra való tekintet nélkül, hogy a szabályozás tárgya tisztán európai integrációs jellegü volt. ${ }^{60}$

Elsősorban a Melchers-esetben kimondottakat a Bosphorus-ítéletben ${ }^{61}$ fejlesztette tovább a Bíróság. Az eset hátterét egy török társaság Yugoslav Airlinestól lízingelt repülőgépének írországi lefoglalása jelentette, amelynek jogalapja a Jugoszláviával szembeni ENSZ BT-határozattal összhangban elfogadott közösség rendelet volt. A Bosphorus nevü társaság és az illetékes ír minisztérium közötti jogvita az Európai Bíróság elé került, amely megállapította, hogy a rendelet céljai tükrében a lefoglalás megfelelő volt és arányos. ${ }^{62}$ Ezt követően került az ügy a strasbourgi testület elé, amely megállapította, hogy az ír hatóságok valóban beavatkoztak a társaság tulajdonjogának gyakorlásába, de ezt a közösségi jogi kötelezettségeik teljesítése céljából tették. ${ }^{63}$ A Bíróság mindezzel összefüggésben azt az általános jellegü vélelmet állította fel, hogy amíg a nemzetközi szervezet tiszteletben tartja az alapvető jogokat, azaz legalább az EJEE-ben foglaltakhoz hasonló mértékü jogvédelmet nyújt, a szervezeti tagságból származó kötelezettségek alapján elfogadott tagállami aktusokat jogszerünek kell tekinteni. E vélelem ugyanakkor megdönthető, ha az egyezményben biztosított jogok védelme nyilvánvalóan elégtelenül történik; ebben az esetben megállapítható az állam felelőssége. ${ }^{64} \mathrm{Az}$ alapjogvédelmi standardok vonatkozásában az ítélet a közösségre nézve kedvező eredménnyel zárult, azonban megteremtette a tagállamok felelősségének megállapításának alapját olyan esetekben is, amikor a tagállamok nem rendelkeznek mozgástérrel az uniós jog végrehajtása vagy implementálása kapcsán. ${ }^{65}$

58 Uo., 27., 31. pontok.

59 Douglas-Scott [2006], 637. o.

60 Matthews v. the United Kingdom, 35-36. pontok.

${ }^{61}$ Bosphorus Hava Yolları Turizm ve Ticaret Anonim Şirketi v. Ireland [GC], no. 45036/98, ECHR 2005-VI, 107. o.

62 1996. július 30-i Bosphorus kontra Minister for Transport, Energy and Communications és társai ítélet, C-84/95, EU:C:1996:312, 26. pont.

63 Bosphorus v. Ireland, 148. pont.

${ }^{64}$ Uo., 155-157. pontok.

65 Szalayné [2009], 390. o. 
Részint a két jogi rezsim - illetve az Európa Tanács és az Európai Unió - közeledésének eredményeként 2004. május 13-án került sor az egyezmény 14. Kiegészítő Jegyzőkönyvének aláírására, amely kialakította annak kereteit, hogy az EU csatlakozzon az EJEE-hez. Egyes részes államokban a ratifikáció elhúzódott, végül a jegyzőkönyv 2010. június 1-jén lépett hatályba. ${ }^{66}$ Az Unióban ezzel párhuzamosan zajlott szerződési reformfolyamat eredményeként az Alkotmányos Szerződés jogalapot teremtett az egyezményhez való csatlakozásra, amely rendelkezést a Lisszaboni Szerződés is átvette. Ennek megfelelően a jelenlegi EUSz 6. cikk (2) bekezdése rögzíti, hogy „Az Unió csatlakozik az emberi jogok és alapvető szabadságok védelméről szóló egyezményhez. Ez a csatlakozás nem érinti az Uniónak a Szerződésekben meghatározott hatásköreit."

E jogalapokkal élve megkezdődtek a tárgyalások a felek között, amelyek eredményeként 2013. április 5-re elkészült a csatlakozás részleteit rögzítő megállapodástervezet. ${ }^{67}$ A dokumentum kapcsán az Európai Bizottság vélemény iránti kérelmet terjesztett az Európai Bírósághoz. A 2/13. számú véleményben ${ }^{68}$ a testület több olyan eshetőséget vizsgált meg, amely az uniós jog által rögzített elvek és eljárások megkerülését tennék lehetővé. ${ }^{69} \mathrm{E}$ körbe tartozott az alperesi pertársaság szabályozásának kérdése is, amely az Unió és a tagállamai közötti felelösség megosztása kapcsán tette volna lehetővé az említett szereplők közötti megállapodás megkötését. Azonban a Bíróság megítélése szerint ez a hatáskörmegosztásra irányadó uniós szabályok értékelését, illetve a luxembourgi testület kizárólagos kompetenciájába tartozó kérdésben való döntés meghozatalát eredményezné. ${ }^{70} \mathrm{~A}$ részletes vizsgálat eredményeként a testület végül arra jutott, hogy a tervezet alkalmas az uniós jog sajátos jellemzöinek és autonómiájának megsértésére. ${ }^{71}$

Az elutasító vélemény miatt az Európai Uniónak az egyezményhez való csatlakozása megakadt, a megállapodástervezet átalakítása ugyan szerepelt az Európai Bizottság munkaprogramjaiban,$^{72}$ de lényegi elörelépés nem történt.

66 Szalayné [2010], 33-35. o.

${ }^{67}$ 2014. december 18-i vélemény, 2/13, EU:C:2014:2454 (2/13. sz. vélemény).

68 2/13. sz. vélemény, 48. pont.

69 Többek között ilyennek minősült az a rendelkezés, amely a tagállamok legmagasabb szintủ bíróságai számára lehetővé tette, hogy tanácsadó vélemény iránti kérelemmel forduljanak a strasbourgi bírósághoz, gyakorlatilag ahelyett, hogy előzetes döntéshozatali eljárás lefolytatását kérnék az Európai Bíróságtól. 2/13. sz. vélemény, 196-200. pontok.

70 2/13. sz. vélemény, 224., 234. pontok.

${ }^{71}$ Uo., 258. pont.

${ }^{72}$ Lásd: http://www.europarl.europa.eu/legislative-train/theme-area-of-justice-and-fundamental-rights/file-completion-of-eu-accession-to-the-echr (2018. 09. 27.) 
Más megközelítést tartalmaz az ENSZ 1982. évi Tengerjogi Egyezménye, amely létrehozta a Nemzetközi Tengerjogi Bíróságot (International Tribunal for the Law of the Sea, ITLOS). ${ }^{73}$ A Záró rendelkezések kifejezetten lehetővé teszik a nemzetközi szervezetek számára a csatlakozást,$^{74}$ de az UNCLOS szövege mégsem tekinti az államokkal megegyező jellegủ részes feleknek ezen entitásokat, ugyanis több helyen akként fogalmaz, hogy az államok a hatáskörrel felruházott nemzetközi szervezeteiken keresztül járnak el. ${ }^{75}$

A részes államokhoz hasonlóan a nemzetközi szervezetek is választhatnak az UNCLOS 287. cikke által felkínált vitarendezési lehetőségek közül, ami alól jellegéből adódóan a Nemzetközi Bíróság képez kivételt. Ha valamely eljárásnak egy nemzetközi szervezet és a tagállama együttesen a felei, a szervezetre úgy kell tekinteni, hogy elfogadta a tagállama által választott vitarendezési módot; amennyiben a tagállam kizárólag a Nemzetközi Bíróságot jelölte meg, az ügyben választott bíróság eljárása lehetséges. ${ }^{76}$

Az UNCLOS-nak az uniós tagállamok és maga az Európai Unió is szerződő felei. Az egyezmény megkötését jóváhagyó tanácsi határozat maga is idézi a IX. mellékletben foglaltakat, illetve utal arra, hogy az ENSZ fötitkáránál elhelyezett megerősítő okmány tartalmaz a hatásköri kérdésekre vonatkozó nyilatkozatot is. ${ }^{77}$

Habár az említett 287. cikk több vitarendezési lehetőséget tesz elérhetővé a csatlakozó államok és nemzetközi szervezetek számára, az egyezmény egyértelmüen prioritásként tekint a Nemzetközi Tengerjogi Bíróságra, amelynek felépítésére és működésére vonatkozó szabályokról szintén külön melléklet szól. ${ }^{78} \mathrm{~A}$ hatásköri szabályok elsődlegesen az UNCLOS-ban részes államok számára teszik lehetővé az eljárást, de ugyanez lehetséges az említett csoportba nem tartozó egyéb entitások

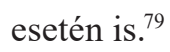

${ }^{73}$ UNCLOS, IV. melléklet.

${ }^{74}$ Uo., 305. cikk. (1) bekezdés f) pont.

75 Például UNCLOS, 197., 202. cikkek.

${ }^{76}$ Uo., 7. cikk (1), (3) bekezdések.

77 A Tanács 98/392/EK határozata (1998. március 23.) az Egyesült Nemzetek Szervezete 1982. december 10-i tengerjogi egyezményének és az egyezmény XI. részének végrehajtásáról szóló, 1994. július 28-i megállapodásnak az Európai Közösség általi megkötéséről, 1. cikk (3) bekezdés.

${ }^{78}$ UNCLOS, VI. melléklet.

${ }^{79}$ Uo., 20. cikk. 
Az ITLOS elé eddig huszonöt ügy került, ${ }^{80}$ amelyek közül az ún. Kardhal-esetben ${ }^{81}$ szerepelt az Európai Unió félként. Hátterét a chilei halászati törvénynek azon állományvédelmi rendelkezései képezték, amelyek megtiltották a nyílt tengeren fogott kardhalmennyiségnek a chilei kikötőkben való kirakodását, illetve az ország területén történő átszállítását. Mivel e rendelkezés hátrányosan érintette a térségben tevékenykedő európai - elsősorban spanyol - halászokat, az Európai Közösség a nemzetközi szintủ fellépés mellett döntött. Mivel mindkét érintett a Kereskedelmi Világszervezet tagja, 2000 áprilisában az EK vitarendezési eljárás lefolytatását kezdeményezte az Általános Vám- és Kereskedelmi Egyezménynek ${ }^{82}$ (General Agreement on Tariffs and Trade, GATT) az átszállítás szabadságát és a nem vámjellegü akadályok tilalmát kimondó rendelkezéseire hivatkozva, illetve az év végén WTO-panel felállítását kérte. Chile ugyanakkor elutasította, hogy a WTO az ügyben hatáskörrel rendelkezne, és az UNCLOS alapján kezdeményezte választott bíróság felállítását. Végül 2000 decemberében a leendő felek a Nemzetközi Tengerjogi Bírósághoz fordultak. ${ }^{83}$

Ahogy a felállított speciális bírói tanács határozataiból kitűnik, Chile és az Európai Közösség már 2001 első felében ideiglenes megállapodást kötött, és kérelmezték a Bíróságtól az eljárás felfüggesztését, majd a következő években ennek többszöri meghosszabbítására került sor. Végül a felek kérelme alapján a tanács 2009. december 16-i határozatával ${ }^{84}$ kimondta az eljárás megszüntetését, tekintettel arra, hogy a felek 2008 októberében kötött megállapodásával okafogyottá vált annak folytatása. ${ }^{85}$ Az e határozat kapcsán kiadott sajtóközleményből kiderül, hogy az ITLOS, illetve az eljáró tanács segítséget nyújtott a felek számára a jogvita „baráti” megoldásához. Ezzel kapcsolatban Chandrasekhara Rao bíró azon megállapításának adott hangot, hogy az igazságszolgáltató funkció ellátásán felül a jogviták békés megoldásában való közremüködés is a testület feladata, amennyiben erre van lehetőség. ${ }^{86}$

${ }^{80}$ Lásd: https://www.itlos.org/en/cases/list-of-cases/ (2018. 10. 05.)

${ }^{81}$ Case No. 7, Case concerning the Conservation and Sustainable Exploitation of Swordfish Stocks in the South-Eastern Pacific Ocean (Chile/European Union). Letölthetö: https://www.itlos.org/ en/cases/list-of-cases/case-no-7/ (2018. 10. 05.)

${ }^{82}$ WTO-egyezmény, 1 A) Melléklet.

${ }^{83}$ Az ügy hátterét és az előzmények bővebb összefoglalóját lásd: Stoll-Vöneky [2002], 21-22. o.

${ }^{84}$ Conservation and Sustainable Exploitation of Swordfish Stocks (Chile/European Union), Order of 16 December 2009, ITLOS Reports 2008-2010, 13. o.

${ }^{85}$ Uo., 15. o.

${ }^{86}$ ITLOS/Press 141, 17 December 2009. Letölthető: https://www.itlos.org/fileadmin/itlos/documents/press_releases_english/PR.141-E.pdf (2018. 10. 05.) 2. o. 
Az Európai Unió nemzetközi jogi felelősségével kapcsolatban a legszélesebb jogygyakorlat a WTO-egyezménnyel létrehozott Kereskedelmi Világszervezet égisze alatt kialakított ún. Vitarendezési Testület tevékenysége nyomán jött létre. Maga a WTOegyezmény a többi nemzetközi szervezettel összehasonlítva eltérő szemléletet tükröz azáltal, hogy a WTO eredeti tagjai között nevezi meg az Európai Közösséget ${ }^{87}$ illetve a vitarendezésre vonatkozó szabályok sem tagállamok, hanem pusztán a tagok eljárásairól szólnak, amelybe az előzőek alapján az Európai Unió is beleértendő. ${ }^{88}$

Az Európai Közösség és a tagállamai közötti felelősség megoszlásával foglalkozó egyik első eset az ún. $L A N$-ügy ${ }^{89}$ volt, amelyben az Egyesült Államok a Vitarendezési Testülettől az EK-val, az Egyesült Királysággal és Î́rországgal szemben külön vizsgálóbizottságok (panelek) felállítását kérte egyes informatikai berendezéseket érintő vámátsorolási igénye alapján, azonban a DSB döntésének megfelelóen végül egy panel járt el. ${ }^{90}$ Az eljárás során az EK elutasította az igény jogosságát, illetve kérte, hogy ne a tagállamai ellen, hanem kizárólag vele szemben folyjon a vizsgálat. ${ }^{91}$ Mindezt azzal is alátámasztotta, hogy a közösségi jog a szuverenitás-átruházás révén kevesebb jogot és kötelezettséget hagy a tagállamoknál, illetve a - panel által is kiemelt - vámunió fennállása nemzetközi kötelezettségek vállalását is eredményezi. ${ }^{92}$

Az ügy jelentőségét a panel azon következtetése adja, amelyben - ha implicit módon is - elismerte, hogy a brit és az ír vámhatóságok az Európai Közösségek szerveiként jártak el. ${ }^{93}$ Ennek megfogalmazása az ún. végrehajtási föderalizmus elismerésének első lépcsőjeként volt értékelhető, amely alapján a WTO az Európai Unió felelősségét állapíthatja meg, ha a tagállami hatóságok uniós jogot alkalmaznak, azaz funkcionálisan az EU szerveiként járnak el..$^{94}$

Az eljáró panel kevésbé volt tekintettel az európai integrációs szervezet és a tagállamaik kapcsolatára az Airbus-ügyben, ${ }^{95}$ amelyben az Egyesült Államok indított

${ }^{87}$ WTO-egyezmény, XI. cikk.

88 2. Melléklet A vitarendezés szabályairól és eljárásairól szóló egyetértés.

${ }^{89}$ European Communities - Customs Classification of Certain Computer Equipment - Report of the Panel (5 February 1998), WT/DS62/R, WT/DS67/R, WT/DS68/R.

${ }^{90}$ Uo., 1.9. pont.

91 Uo., 3.3. pont.

${ }_{92}$ Uo., 4.14-4.15. pontok. Kuijper-Paasvirta [2013], 60. o.

${ }_{93}$ Uo., 8.16. pont.

${ }^{94}$ Delgado Casteleiro-Larik [2013], 243. o

95 European Communities and Certain Member States - Measures Affecting Trade in Large Civil Aircraft - Report of the Panel (30 June 2010), WT/DS316/R. 
eljárást az EK-val és négy tagállamával szemben a címben említett repülőgépgyár számára különféle formában nyújtott, tiltott támogatás miatt. Az EK ebben az esetben is egyedül kívánt volna részt venni az eljárásban, ${ }^{96}$ de a panel ezt végül elutasította. A jelentés megerősítette annak lehetőségét, hogy az EK felelösséget viseljen a tagállamai aktusaiért, ugyanakkor kiemelte, hogy ez nem csökkenti azon jogokat és kötelezettségeket, amelyek az érintett államokat WTO-tagként megilletik. Az elhatárolás élességét azzal is alátámasztotta, hogy az EK és a tagállamai közötti felelősségi viszonyokat belső kérdésnek minősítette. ${ }^{97}$

Ami az EU és a tagállamok WTO-beli eljárásait alapjaiban áthatja, az az ún. lojális együttmüködés elve, amely alapján egymást kölcsönösen megsegíteni kötelesek. ${ }^{98}$ Ez a WTO égisze alatt folyó tárgyalások egy jelentős része kapcsán érvényesül, amelyek során számos esetben akkor is a Bizottság jár el, amikor megosztott hatáskörbe eső kérdésről van szó, ${ }^{99}$ ugyanakkor a tagállamok ragaszkodnak a létrehozott megállapodás aláírásához. ${ }^{100}$ De ez megnyilvánul abban is, hogy több esetben a (korábban) tagállami hatáskörbe tartozó kérdések vonatkozásában a közösség, illetve az Unió eljárása révén értek el megoldást. ${ }^{101}$

\section{IV.5. Az Európai Unió Bírósága}

Első látásra meglepőnek tünhet, hogy az EU nemzetközi jogi felelősségi kérdéseivel foglalkozó bírói fórumok közül miért az Európai Bíróság kerül utolsóként sorra. Erre magyarázatként az szolgál, hogy a testület elsődleges feladata az uniós jog megfelelő értelmezésének biztosítása, ${ }^{102}$ amely azt eredményezi, hogy nemzetközi jogi kérdésekkel csak speciális esetekben foglalkozik, ${ }^{103}$ akkor is uniós jogi szempontok alapján.

${ }^{96}$ Uo., 4.2. pont.

${ }^{97}$ Uo., 7.14-7.15. pontok. Kuijper-Paasvirta [2013], 62. o.

98 EUSz 4. cikk (3) bekezdés.

${ }^{99}$ Lásd: 2009. november 30-i vélemény, 1/08, EU:C:2009:739, amely a Szolgáltatások Kereskedelméről szóló Általános Egyezménnyel (General Agreement on Trade in Services, GATS) volt kapcsolatos.

${ }^{100}$ Delgado Casteleiro-Larik [2013], 251. o

${ }^{101}$ Ireland - Measures Affecting the Grant of Copyright and Neighbouring Rights (WT/DS82) European Communities - Measures Affecting the Grant of Copyright and Neighbouring Rights (WT/ DS115) - Notification of Mutually Agreed Solution (13 September 2002), IP/D/8/Add.1, IP/D/12/Add.1, WT/DS82/3, WT/DS115/3 - idézi Delgado Casteleiro-Larik [2013], 242. o.

${ }^{102}$ EUSz 19. cikk.

${ }^{103}$ Lásd: Európai Unió Múködéséről szóló Szerződés (EUMSz) 218. cikk (11) bekezdése, amely a tervezett nemzetközi szerződések kapcsán teszi lehetővé vélemény kibocsátását, illetve 2008. szeptember 3-i Kadi ítélet, C-402/05. P. és C-415/05. P. sz. egyesített ügyek, EU:C:2008:461. 
A Bíróságnak a nemzetközi jogi szerződéses felelősséggel foglalkozó gyakorlata leginkább az EU és a tagállamai közötti hatáskörmegosztásra fókuszál. A későbbi fejlődés vonatkozásában kiemelendő az 1/78. számú döntés, ${ }^{104}$ amelynek tárgya az Európai Atomenergia-közösségnek a nukleáris anyagok, létesítmények és szállítmányok védelméről szóló egyezményben való részvétele volt. A Bíróság álláspontja szerint a feladatok és hatáskörök megosztásának rendszeréröl nem szükséges tájékoztatni az egyezmény többi részes felét, ugyanis ezek belső kérdésnek minősülnek, amelyek idővel változhatnak. ${ }^{105}$

A Bíróság ezen álláspontját később módosította, ${ }^{106}$ amely mögött vélhetően az 1982. évi Tengerjogi Egyezményben megjelenő, a nemzetközi szervezetek számára hatásköri nyilatkozat megtételét elöíró követelmény, illetve e dokumentumok elterjedése állt. E nyilatkozattételi kötelezettség kizárólag a többoldalú nemzetközi szerződésekben szerepelt, és a kétoldalú megállapodásai vonatkozásában az EU nem is élt vele, ami mögött az húzódik, hogy az ilyen jellegű dokumentum korlátozná a hatáskörök későbbi rögzítésére vonatkozó mozgásterét. ${ }^{107}$

Sajátos módon a Bíróság egy bilaterális jellegű megállapodás kapcsán fogalmazott meg következtetéseket az ilyen nyilatkozatokkal, illetve a kapcsolódó felelősségi kérdésekkel összefüggésben. A Parlament kontra Tanács-ügy ${ }^{108}$ előzményét az ún. negyedik loméi egyezmény ${ }^{109}$ alapján elfogadott, pénzügyi tárgyú rendelet kapcsán indított semmisségi eljárás képezte. A negyedik loméi egyezményt egyrészt az afrikai, karibi és csendes-óceáni (AKCS) államok, másrészt az Európai Gazdasági Közösség és annak tagállamai vegyes szerződésként 1989-ben kötötték meg. A felelősségi kérdéseket tárgyalva a Bíróság kiemelte, hogy az egyezmény bilaterális jellegű együttműködést hozott létre a szerződő felek között, amely alapján az EGK és a tagállamai „közösen felelősek” az egyezményben foglalt kötelezettségek teljesítéséért, amennyiben abban nem szerepel ettől eltérő rendelkezés. ${ }^{110} \mathrm{Az}$ ítélet egyéb elemeinek kontextusában lényeges, hogy e megállapítás a szerződések egészére irányadó. ${ }^{111}$

104 1978. november 14-i döntés, 1/78, EU:C:1978:202.

${ }^{105}$ 1/78. sz. döntés, 34-35. pontok.

106 Cremona [2008], 39-40. o.

${ }^{107}$ Heliskoski [2013], 209. o.

108 1994. március 2-i Parlament kontra Tanács ítélet, C-316/91, EU:C:1994:76. (Parlament kontra Tanács ítélet).

109 91/400/ECSC, EEC: Decision of the Council and the Commission of 25 February 1991 on the conclusion of the fourth ACP-EEC Convention. HL L 229., 1991.8.17., 1. o.

${ }^{110}$ Parlament kontra Tanács ítélet, 29. pont.

111 Rosas [2013], 153-154. o. 
Mindezt a Hermès-ítéletében ${ }^{112}$ a WTO-egyezménnyel összefüggésben is megerősítette a Bíróság. Megállapította, hogy az egyezményt a közösség kötötte, és a tagállamok kihirdették anélkül, hogy a többi szerződő fél irányába fennálló kötelezettségekkel kapcsolatok hatáskörökről nyilatkoztak volna. ${ }^{113}$ Az előzőek fényében ebből az a következtetés vonható le, hogy az EU és a tagállamok a WTO-egyezmény egészéért felelősek. ${ }^{114}$

Szintén vegyes szerződésekkel összefüggő, sajátos felelösségi kérdések jöttek elő a Bizottság kontra Franciaország-ügyben, ${ }^{115} \mathrm{Az}$ eset hátterét a Földközi-tenger szennyezés elleni védelméről szóló, 1976. évi egyezmény, ${ }^{116}$ illetve az ehhez kapcsolódóan kötött, a Földközi-tenger szárazföldi eredetủ szennyezés elleni védelméröl szóló, 1980. évi jegyzökönyv ${ }^{117}$ képezte, amely szerződéseknek az Európai Unió és tagállamai és részes felei. Mivel Franciaország nem tette meg a megfelelő intézkedéseket a Marseille melletti Berrei-tó szennyezésének megelőzésére, illetve csökkentésére, az említett nemzetközi szerződések megszegése alapján a Bizottság kötelezettségszegési eljárást indított vele szemben.

A francia kormány arra alapozva vitatta a Bíróság hatáskörét, hogy ez nem uniós jogi - hanem jellegéből adódóan nemzetközi jogi - kérdés, illetve ezzel öszszefüggésben azt is érvként hozta fel, hogy nem született a konkrét tárgykört ${ }^{118}$ szabályozó uniós irányelv. ${ }^{119}$ Válaszában a testület egyrészt utalt a Demirel-ítéletben ${ }^{120}$ kimondottakra, amely szerint a tagállamok a vegyes szerződések teljesítésért is az Uniónak tartoznak felelősséggel, illetve ezt továbbfejlesztve kimondta, hogy mivel az egyezmény és a jegyzőkönyv is az uniós jog által „nagymértékben lefedett területen" teremt jogokat és kötelezettségeket, uniós érdeknek minősül, hogy az EU és a tagállamok is eleget tegyenek az említett nemzetközi szerződé-

112 1998. június 16-i Hermès-ítélet, C-53/96, EU:C:1998:292 (Hermès-ítélet).

113 Hermès-ítélet, 24. pont.

114 Delgado Casteleiro-Larik [2013], 237-238. o

115 2004. október 7-i Bizottság kontra Franciaország-ítélet, C-239/03, EU:C:2004:598 (Bizottság kontra Franciaország-ítélet).

116 A Tanács 77/585/EGK határozata (1977. július 25.) a Földközi-tenger szennyezés elleni védelméről szóló egyezmény megkötéséről, valamint a Földközi-tenger hajókról és légi járművekről történő kidobással okozott szennyezésének megelőzéséről szóló jegyzőkönyv elfogadásáról. HL L 240., 1977.9.19., 1. o.; magyar különkiadás: 11. fejezet, 12. kötet, 135. o.

117 A Tanács 83/101/EGK határozata (1983. február 28.) a Földközi-tenger szárazföldi eredetű szennyezés elleni védelméről szóló jegyzőkönyv elfogadásáról. HL L 67., 1983.3.12., 1. o.; magyar különkiadás 11. fejezet, 15. kötet, 99. o.

118 A sós tóba történő édesvíz- és hordalék-kibocsátást.

119 Bizottság kontra Franciaország-ítélet, 22. pont.

120 1987. szeptember 30-i Demirel-ítélet, 12/86, EU:C:1987:400, 11. pont. 
sekben foglaltaknak. ${ }^{121}$ Ezen esetben a közös nemzetközi jogi felelősség egy sajátos esetéröl volt tehát szó, amelyet a Bíróság összefüggésbe hozott a tagállamok uniós jogi felelősségével. ${ }^{122}$

\section{Konklúzió}

A második világháborút követő évtizedek jogfejlödésének eredményeként a nemzetközi szervezetek jogi személyisége általánosan elfogadottá vált, e folyamat nem járt azzal, hogy az e státuszhoz köthető jogképesség és hatáskörök megegyeznének az államokéval, különösen igaz ez a nemzetközi felelősség tárgykörére. A nemzetközi közösség erre irányuló szándékának hiányát jelzi, hogy sem az államok, sem a nemzetközi szervezetek felelössége vonatkozásában nem sikerült pusztán megállapodástervezetekről beszélhetünk, nem nemzetközi szerződésekről.

Habár felemás eredményekről beszélhetünk e téren, az európai integrációs szervezetek létrehozása és fejlődése nagyban hozzájárult a nemzetközi szervezetek „felzárkózásához” azzal együtt, hogy éppen az Európai Unió vonatkozásában érezhetők a jelenlegi rendszer hiányosságai, ami különösen igaz a bírói fórumokhoz való hozzáférésre. Mindazonáltal az Európai Közösségek, illetve az EU felelősségi kérdéseivel összefüggő nemzetközi joggyakorlat - elsődlegesen a Kereskedelmi Világszervezet vitarendezési eljárásai során keletkezett esetjog - modellértékűvé vált.

A fent elemzett esetek alapján egy olyan tendencia rajzolódik ki, hogy a különböző nemzetközi bírói fórumok előtt a tagállamok szívesen fogadják, ha az Európai Unió nemcsak tárgyal helyettük, hanem olyan tárgykörökben is hajlandó egyedüli felelősséget vállalni, amelyek nem tartoznak a kizárólagos hatáskörébe. Szintén több fórum esetén megfigyelhető, hogy az EU - amennyiben ez lehetséges - törekszik a jogvitában álló féllel „,békés” megoldások kialakítására, amely több esetben részletkérdést rendező nemzetközi szerződés megkötését jelentette.

Az Európai Bíróság korábbi véleményével szemben az Európai Unió nemzetközi jogi felelőssége nem függetleníthető az integrációs szervezet és a tagállamai között fennálló hatáskörök jellegétől. Ezt a hatásköri nyilatkozatok megtételére vonatkozó, a nemzetközi szervezeteket terhelő kötelezettség megjelenése idézte elő a nyolcvanas évektől, napjainkra ez már odáig jutott, hogy nemcsak a többoldalú, hanem a bilaterális szerződések kapcsán is ajánlja ilyenek megtételét a Bíróság. Szintén e

${ }^{121}$ Bizottság kontra Franciaország ítélet, 26., 28-29. pontok.

${ }^{122}$ Kuijper [2010], 210. o. 
testület joggyakorlatából ered az a megállapítás, hogy a nemzetközi jog, illetve az uniós jog alapján fennálló felelősség között számos esetben nem áll fenn éles határ, gyakoribb az átfedés a két kategória között, amely elősegíti a különböző nemzetközi jogi rezsimek hatékony érvényesülését.

\section{Irodalomjegyzék}

Cremona, Marise [2008]: Defining competence in EU external relations: lessons from the Treaty reform process. In: Dashwood, Alan - Marescu, Marc (szerk.): Law and Practice of EU External Relations: Salient Features of a Changing Landscape. Cambridge University Press, Cambridge, 34-69. o.

Delgado Casteleiro, Andrés - Larik, Joris [2013]: The 'Odd Couple': The Responsibility of the EU at the WTO. EU International Responsibility and its Attribution: From Inside Looking Out. In: Evans, Malcolm - Koutrakos, Panos (szerk.): The International Responsibility of the European Union. Hart, Oxford - Portland (Oregon), 233-255. o.

Douglas-Scott, Sionaidh [2006]: A Tale of Two Courts: Luxembourg, Strasbourg and the Growing European Human Rights Aquis. Common Market Law Review, Vol. 43., 629-665. o.

Evans, Malcolm - Okowa, Phoebe [2013]: Approaches to Responsibilities in International Courts. In: Evans, Malcolm - Koutrakos, Panos (szerk.): The International Responsibility of the European Union. Hart, Oxford - Portland (Oregon), 101-137. o.

Gaja, Giorgio [2014]: Articles on the Responsibility of International Organizations, Introductory note. United Nations. Letölthetö: http://legal.un.org/avl/pdf/ha/ario/ario_e.pdf

Heliskoski, Joni [2013]: EU Declarations of Competence and International Responsibility. In: Evans, Malcolm - Koutrakos, Panos (szerk.): The International Responsibility of the European Union. Hart, Oxford - Portland (Oregon), 189-212. o.

Kuijper, Pieter Jan [2010]: International Responsibility for EU Mixed Agreements. In: Hillion, Christophe - Koutrakos, Panos (szerk.): Mixed Agreements Revisited - The EU and its Member States in the World. Hart, Oxford - Portland (Oregon), 208-217. o.

Kuijper, Pieter Jan - Paasvirta, Esa [2013]: EU International Responsibility and its Attribution: From Inside Looking Out. In: Evans, Malcolm - Koutrakos, Panos (szerk.): The International Responsibility of the European Union. Hart, Oxford - Portland (Oregon), 35-71. o.

Lamm Vanda [1995]: A Nemzetközi Bíróság ítéletei és tanácsadó véleményei 1945-1993. Közgazdasági és Jogi Könyvkiadó, Budapest, 549 o.

Rosas, Allan [2013]: International Responsibility of the EU and the European Court of Justice. In: Evans, Malcolm - Koutrakos, Panos (szerk.): The International Responsibility of the European Union. Hart, Oxford - Portland (Oregon), 139-159. o.

Stoll, Peter-Tobias - Vöneky, Silja [2002]: The Swordfish Case: Law of the Sea v. Trade. Zeitschrift für ausländisches öffentliches Recht und Völkerrecht, Vol. 62., 21-35. o.

Szalayné Sándor Erzsébet [2009]: Az alapjogok három jogrendszer metszéspontján. Állam- és Jogtudomány, 1. sz., 365-398. o.

Szalayné Sándor Erzsébet [2010]: Új távlatok az európai alapjogvédelemben - Hatályba lépett az Egyezmény 14. Kiegészítö Jegyzőkönyve. Közjogi Szemle, 3. sz., 33-40. o.

Wessel, Ramses A. - Den Hertog, Leonhard [2013]: EU Foreign, Security and Defence Policy: A Competence-Responsibility Gap? In: Evans, Malcolm - Koutrakos, Panos (szerk.): The International Responsibility of the European Union. Hart, Oxford - Portland (Oregon), 339-358. o. 